Corresponding Author: Dayana Noprida; email:

nopridaarifin@gmail.com

Published: 7 February 2022

Publishing services provided by Knowledge E

(c) Nyimas Heny Purwati et al. This article is distributed under the terms of the

which permits unrestricted use and redistribution provided that the original author and source are credited.

Selection and Peer-review unde the responsibility of the IVCN Conference Committee.

\section{Impact of Age and Gender on the Incidence of COVID-19 in Children at Pasar Rebo Hospital, Jakarta}

\section{Nyimas Heny Purwati, Dayana Noprida*, Wahyuni Agustia, Tri Imroatun, Sarini Sarini, Sahariah Sahariah, and Damayanti Polapa}

Faculty of Nursing Science, University of Muhammadiyah Jakarta, Indonesia

\section{ORCID}

Dayana Noprida: https://orcid.org/0000-0001-8384-7749

Abstract. SARS-CoV-2 is a new type of coronavirus that has never been previously identified in humans. COVID-19 can cause respiratory system disorders, ranging from mild symptoms such as flu, to lung infections, such as pneumonia. The average incubation period is 5-6 days with the longest incubation period being 14 days. This virus spread rapidly around the world, including to Indonesia. From March 2, 2020 to July 9, 2020, Indonesia reported 70,736 confirmed COVID-19 cases and 3,417 deaths (CFR 4.8\%). Based on data obtained from the Indonesian Pediatrician Association, 416 out of 72,314 cases confirmed positive for COVID-19 (0.9\%) were children aged less than 10 years, $549 / 72,314$ or $1 \%$ were children aged $10-19$ years, and 450 of them had died by March 21, 2020. This study aimed to examine the relationship between age and gender with the incidence of COVID-19 in children at Pasar Rebo Hospital, Jakarta. Data collection used secondary data, the sample included 150 respondents, and the research instrument used was observation sheets at Pasar Rebo Hospital, Jakarta. The design of this study was quantitative cross-sectional. This research used the Chi-square test and t-test for data analysis. A total of $57.3 \%$ of respondents were male, and $42 \%$ had symptoms. According to the findings, there was a relationship between age and gender with the incidence of COVID-19 in children $(p<0.001)$. Male children were more at risk of being infected with COVID-19 than females, likely due to differences in the immunological system related to gender as women have a lower susceptibility to viral infections than men. Based on the results, there was also a relationship between age and the incidence of COVID-19 in children at the hospital. These results have implications for differences in the nursing care that is needed for boys vs. girls with COVID-19.

Keywords: COVID-19, children, age, gender

\section{Introduction}

Coronavirus Disease 2019 (Covid 19) is an infectious disease caused by Severe Acute Respiratory Syndrome Coronavirus 2 (SARS-CoV-2). SARS-CoV-2 is a new type of coronavirus that has never been previously identified in humans. COVID-19 can cause respiratory system disorders, ranging from mild symptoms such as flu, to lung infections, 
incubation period being 14 days. The outbreak of Coronavirus Disease 2019 (COVID-19) was first reported in Wuhan, China, on December 31, 2019. Covid 19 spread rapidly, from between provinces in China to other countries in the world. This rapid spread has become a world emergency, and at the end of January 2020 the World Health Organization (WHO) declared Covid 19 a public health emergency of international concern (PHEIC).

In March 2020, there were 118,319 cases in 114 countries, and 4,291 people died. Finally on March 11, 2020, Covid 19 was declared a pandemic. according to [1] Covid19 cases do not only occur in adults but also occur in children in both developed and developing countries. There are 209,839 cases of COVID-19 with more than 170 countries affected by COVID-19. The case fatality reached 8,778 with a case fatality rate of $4.18 \%$. The incidence of COVID-19 in children is not as much as in adults, and most children with confirmed COVID-19 get it from their families. According to [2]. The incidence of COVID-19 in children aged 10-19 years was 549 out of 72,314 or $1 \%$ of all cases, while the age group < 10 years was 416/72,314 (0.9\%). Cases of Covid 19 have also been shown to occur in neonates with the first case reported in Wuhan, China in a neonate aged 3 days. Cases of COVID-19 are rare in newborns, with nine children being hospitalized being diagnosed with Covid-19 in China. In Italy, reported that only $1.2 \%$ of 22,512 cases with Covid 19 were children without death. Of the 4226 cases of Covid 19 detected in the US 5\% were children. In Germany there were 2 confirmed children, and in the Philippines 1 child aged 5 years was also confirmed to have Covid 19.

According to the United States Department of Health and Human Services, cases of infants and children accounted for $22 \%$ of the pediatric population, and in adolescents reported as many as 2,572 cases. The mean age 11 years (range 0-17 years), as many as 813.32\% occurred in children aged $15-17$ years, $682.27 \%$ in children aged $10-14$ years. Children who are less than 1 year old are around 398 (15\%), 291 years old 1-4 years (11\%), and 5-9 years old are 388 (15\%). In this pediatric case, among 2,490 cases in children, $1,408(57 \%)$ occurred in boys, and among $184(7.2 \%)$ in children aged less than 18 years, it was found that $16(9 \%)$ originated from travel. , and as many as $168(91 \%)$ of COVID-19 patients from the community or household [1]

This virus spread rapidly in various worlds, even to Indonesia. From $2^{\text {nd }}$ March 2020 to $9^{\text {th }}$ July 2020, Indonesia reported 70,736 confirmed COVID-19 cases and 3,417 deaths (CFR 4.8\%). Based on the data obtained from[2] children aged less than 10 years who were confirmed positive for COVID-19 were 416/72,314 (0.9\%) cases, children aged 1019 years were $549 / 72,314$ or $1 \%$ of the total cases, and 450 cases of them died. until $21^{\text {th }}$ March 2020. 
In addition to age, other risk factors for the incidence of Covid-19 in children, according to IDAI (2020). That can be through a history of close contact with a confirmed case of a positive Covid-19 person or contact with a probable case. Close contact means children who live in the same house or are in the same room, whether it's mass gatherings and day care centers with confirmed positive or probable cases of Covid-19. according to [3] which noted that of the 20 cases of Covid-19 in children, 13 cases of Covid-19 children (65\%) had a history of contact with family members who were confirmed to be Covid19. About 36\% were exposed in hospital. Transmission at the hospital occurred due to contact between medical staff and patients, one of whom was infected with COVID-19. Another factor that can affect the occurrence of COVID-19 in children is gender. Because gender is related to the level of immunity. Men are much more susceptible to Covid than women.

The results of literature research conducted [4] mentions that there is a relationship between gender and the incidence of COVID-19, namely that men are more at risk than women. This happens because of chromosomal factors with hormonal factors. The female sex is more protected from COVID-19 because it has an $X$ chromosome and progesterone hormone.

Based on medical record data and the results of a survey conducted in the children's isolation room at Pasar Rebo Hospital, Jakarta, it was found that 150 children who were confirmed to have COVID-19 in March-May 2021 were generally male, namely 24 children (57\%) and the majority were aged 7-12 years, namely 14 patients (33.3\%) [5].

The phenomenon of Covid-19 has become a worldwide concern. This Covid-19 has greatly caused anxiety and fear in the community, both globally and in Indonesia. One of the things that causes unrest and fear in the community is its massive and fast spread Covid-19 can infect various age groups from the elderly, adults and children, both in developed and developing countries. The incidence of COVID-19 in children is not as much as adults. The death rate of children due to the coronavirus in Indonesia is the highest in Asia Pacific.

The incidence of Covid-19 in children is not as much as adults, and most children who are confirmed to have Covid-19 get it from their families or there is a history of close contact with a confirmed case of COVID-19. Children of all ages are susceptible to Covid-19, especially babies are very susceptible to infection another factor that can affect the occurrence of COVID-19 in children is gender. Because gender is related to the level of immunity. Men are much more susceptible to Covid than women. Based on the description above, the researcher is interested in conducting research on "the 
TABLE 1: Distribution of respondents by gender.

Variable
Gender
1. Male
2. Female
Total
Age

Frequency
86
64
150
Mean/sd 8,49/5,706

Percentage
$57.3 \%$
$42.7 \%$
100
Min/max 1-17

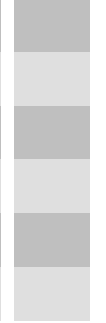

TABLE 2: Age Relationship with Covid 19 Incidence in Children

\begin{tabular}{|l|l|l|l|l|}
\hline Variable & mean & SD & p value & $95 \% \mathbf{C l}$ \\
\hline Age & 8.49 & 5,706 & 0.000 & $(7.57-9.41)$
\end{tabular}

relationship between age and sex with the incidence of COVID-19 in children at Pasar Rebo Hospital, Jakarta".

\section{Methods}

This study is an observational study using a chi square research design to determine the relationship between age and gender characteristics, while the $T$ test is with the incidence of COVID-19 in children at Pasar Rebo Hospital, Jakarta. The sampling technique used a total sampling technique : all children in the pediatric ward at Pasar Rebo Hospital, Jakarta, as many as 150 children with positive PCR. The data collection technique used secondary data with the research instrument using an observation sheet in Jakarta's Pasar Rebo hospital room.

\section{Result}

Based on the table above, there are 86 male respondents (57.3\%) and 64 (42.7\%). It was concluded that the pediatric patients at Pasar Rebo Hospital were boys. And that the average age of children in Pasar Rebo Hospital is 1-17 years old.

Based on table 3 above thatAge is related to the incidence of covid 19 because it is based on a pre-existing medical condition. Children aged 2-6 years are the age most often admitted to the ICU, where the P Value is 0.000 and less than 0.05 ( Ho is accepted). A lower risk of COVID severity was associated with a higher age of the child while a higher severity was associated with a lower age.

This is supported by research from [6]that extreme age $<10$ years and $<1$ year is a risk factor for more severe cases of covid 19. according to [7] Lower age and a history of 
TABLE 3: The Relationship of Sex with the Incidence of Covid 19 in Children

\begin{tabular}{|c|c|c|c|c|c|c|c|}
\hline \multirow[t]{3}{*}{ Variable } & \multicolumn{4}{|c|}{ Covid incident } & \multicolumn{2}{|c|}{ Total } & \multirow[t]{3}{*}{$p$ value } \\
\hline & \multicolumn{2}{|c|}{ With symptoms } & \multicolumn{2}{|c|}{ No symptoms } & \multirow[t]{2}{*}{$n$} & \multirow[t]{2}{*}{$\%$} & \\
\hline & $n$ & $\%$ & $n$ & $\%$ & & & \\
\hline \multicolumn{8}{|l|}{ Gender } \\
\hline 1. Male & 63 & 42 & 23 & 15.3 & 86 & 57.3 & 0.000 \\
\hline 2. Female & 47 & 31.4 & 17 & 11.3 & 64 & 42.7 & \\
\hline
\end{tabular}

comorbidities are the most common risk factors for children with chronic lung disease, obesity, and neurological and developmental disorders.

Based on table 4 above, it shows that children with male sex are more at risk of being infected with covid 19 than female sex. This is due to differences in the immunological system related to gender. Women have a lower susceptibility to viral infections than men. 2 The $X$ chromosome and female sex hormones are said to play a very important role in the innate (natural/nonspecific) immune response and the adaptive (specific) immune response in the pathogenesis of infectious diseases. The female sex is more protected from Covid 19 because it has an $X$ chromosome and has the hormone progesterone.

This is in line with research from [6] and [4]where men are more susceptible to Covid 19. Children with Hispanic and black races also dominate the incidence of Covid 19 which is more severe in children. However, the male gender also dominated children with a diagnosis of covid 19 but did not predict a more severe Covid 19 than the female gender.

\section{Discussion}

In this study, we only looked at gender and age variables, it is better to complete and validate the factors that can be related to the incidence of Covid-19, we can look at other variables such as the variable history of vaccination and immunization status.

\section{Conclusion}

Based on the results of this study, there is a relationship between age and the incidence of covid 19 in children at Pasar Rebo Hospital Jakarta and there is a sex relationship with the incidence of Covid 19 in children at Pasar Rebo Hospital Jakarta. A total of $57.3 \%$ of respondents were male, with as many as $42 \%$ with symptoms. 


\section{Research Suggestions}

Based on the results of the research that has been done, some suggestions can be given, namely:

\section{For respondents}

To provide information that the lower sex and age are more susceptible to covid 19 so that respondents can improve their immune status and better nutrition, for example, babies receive exclusive breastfeeding for 6 months and continue until the age of 2 years. Morning sunlight is also a source of vitamin D which can increase children's immune system.

\section{For the next researcher}

2. It is hoped that further researchers who wish to conduct research with the same title are expected to consider other risk factors such as comorbidities and the severity of COVID-19 symptoms.

3. It is hoped that further researchers will examine nursing interventions applied to children with post covid 19 and how to increase immunity so that reinfection does not occur.

4. For Hospital

As information that can be applied by hospitals to be able to improve nursing care services for children with COVID-19.

\section{References}

[1] Burrer SL, de Perio MA, Hughles MM, Kuhar DT, Luckhaupt SE, McDaniel CJ et al. CDC COVID-19 Response Team. Characteristics of Health Care Personnel with COVID-19 - United States, February 12-April 9, 2020. Centers for Disease Control and Prevention. Mmwr. 2020;69(15):477-81.

[2] IDAl. Panduan Klinis Tata Laksana COVID-19 Pada Anak. Indones Pediatr Soc. 2020;33.

[3] CaiJiehao XJ, Daojiong L. A Case Series of children with 2019 novel coronavirus infection: clinical and epidemiological features. Clin Infect Dis ciaa. 198.

[4] Hidayani WR. Faktor Faktor Risiko Yang Berhubungan Dengan COVID 19: Literature Review. J Untuk Masy Sehat. 2020;4(2):120-34. 
[5] Agustini H. Pelaksanaan Kode Penyakit dan Kode Tindakan di Klinik Bedah Rumah Sakit Umum Daerah Pasar Rebo. MEDICORDHIF J Rekam Medis. 2016;3:1.

[6] Graff K, Smith C, Silveira L, Jung S, Curran-Hays S, Jarjour J, et al. Risk Factors for Severe COVID-19 in Children. Pediatr Infect Dis J. 2021;40(4):E137-45.

[7] She J, Liu L, Liu W. COVID-19 epidemic: Disease characteristics in children. J Med Virol. 2020;92(7):747-54. 